\title{
Bordenkircher $v$. Hayes: Ignoring Prosecutorial Abuses in Plea Bargaining
}

In Bordenkircher v. Hayes, ${ }^{1}$ the United States Supreme Court upheld a conviction on a charge the prosecutor admittedly filed solely because the defendant refused to plead guilty to another set of charges. ${ }^{2}$ Hayes is a sudden departure from a line of cases in which the Court refused to allow prosecutorial charging decisions to be made to discourage a criminal defendant from exercising constitutional or procedural rights. The decision effcctively removes plea bargaining from its constitutional premise: the "mutuality of advantage" between the prosecutor and the defendant. Rather than approving the broad exercise of prosecutorial discretion in plea negotiations, the Hayes Court should have developed an administrable set of rules to prohibit using the prosecutor's charging power for tactical advantage.

\section{The Decrsion}

Paul Hayes initially was indicted for uttering a forged instrument in the amount of $\$ 88.30$, a crime punishable at that time by two to ten years in prison. ${ }^{3}$ After arraignment, the prosecuting attorney met with Hayes and his counsel to discuss a plea bargain. The prosecutor offered to recommend a five-year sentence in return for a guilty plea. He also threatened Hayes with reindictment as a habitual criminal if

1. 434 U.S. 357 (1978).

2. Id. at $361 \&$ n.7.

3. Id. at 358; KY. REv. STAT. $\$ 434.130$ (repealed 1974). The statute provided:

Forgery or counterfeiting of writings. - (1) Any person who forges or counterfeits any writing in order to obtain fraudulently the possession of or to deprive another of any money or property, or to cause another to be injured in his estate or lawful rights, or any person who utters and publishes such an instrument as true, knowing it to be forged and counterfeited, shall be confined in the penitentiary for not less than two (2) nor nore than ten (10) years.

(2) Any person who forges or counterfeits a bank bill, or note or check or draft upon a bank, or the certificate of deposit of money of any bank or company authorized by the United States, any state of the United States or any foreign government, or any imdorseinent on such instruments; who erases or alters it, or any indorsement, or tenders in payment, utters, vends, exchanges, barters or deinands to have exchanged for money any forged, altered or counterfeited bill, note, draft, check or certificate of deposit or the indorsement on such an instrument, knowing it to be forged, counterfeited or altered, shall be confined in the penitentiary for not less than two (2) nor more than ten (10) years. 
Hayes did not consent to such a plea. ${ }^{4}$ Hayes rejected the plea offer, and the prosecutor reindicted him as a habitual offender. Hayes subsequently was convicted on both counts, and therefore was sentenced to a mandatory life prison term. ${ }^{5}$

After exhaustimg state appeals, Hayes filed a habeas corpus writ in federal court, challenging the increased pumshment as unconstitutionally vindictive. ${ }^{6}$ The district court denned the writ, but the Court of Appeals for the Sixth Circuit reversed. ${ }^{7}$ The Supreine Court, however, reinstated the district court's decision. Justice Stewart, writing for the majority, recognized that the prosecutor's threat of harsher pumishment might have a "discouraging effect" upon a defendant's decision to exercise the right to trial. He nevertheless found this "inevitable" in a plea bargaining systein. ${ }^{8}$ Because the Court had "tolerat[ed] and encourag[ed] the negotiations of pleas," Justice Stewart reasoned that it had also "necessarily accepted" as legitimate a prosecutorial interest in persuading the defendant to forego trial. ${ }^{9}$ The Court distinguished cases cited by Hayes which forbade the government from punishing criminal defendants for exercising certain legal rights. The Court was unwilling to characterize the prosecutor's charging tactics in Hayes as vindictive since the defendant had been free to accept or reject the prosecutor's offer.

\section{II}

\section{Analogous Case Law}

The Court has consistently condemned charging decisions in which the prosecutor is inotivated by an intent to inhibit a defendant's exercise of legal rights. In Oyler $v$. Boles, ${ }^{10}$ the Court noted that the prosecutor is entitled to "some selectivity" in determining who will be

4. See KY. Rev. STAT. $§ 431.190$ (repealed 1975). Under this statute, any person convicted of a third felony was subject to a mandatory life term. The statute provided:

Conviction of felony-Punishment on second and third offenses.-Any person convicted a second time of felony shall be confined in the penitentiary not less than double the time of the sentence under the first conviction; if convicted a third time of felony, he shall be confined in the penitentiary during his life. Judgment in such cases shall not be given for the increased penalty unless the jury finds, from the record and other competent evidence, the fact of former convictions for felony committed by the prisoner, im or out of this state.

Hayes had two prior convictions that indispufably brought him under the terms of this statute. Under curreut state law Hayes would be subject to a maximum term of twenty years imprisonment. KY. Rev. Stat. § 532.080 (1977).

5. 434 U.S. at 359 .

6. Id. at 360 .

7. Hayes v. Cowan, 547 F.2d 42, 44 (6th Cir. 1977), rev'd sub nom. Bordenkircher v. Hayes, 434 U.S. 357 (1978). The Court of Appeals rehed principally on Blackledge v. Perry, 417 U.S. 21 (1974), which reversed a felony conviction obtained by a prosecutor after a defendant had appealed a misdemeanor conviction for the same conduct.

8. 434 U.S. at 364.

9. Id.

10. 368 U.S. 448 (1962). 
prosecuted, and that the mere fact that others have not been prosecuted for conduct similar to that for which the defendant has been charged does not amount to a constitutional violation. The Court held, however, that a defendant could nevertheless defend by showing that the decision to charge the defendant was "deliberately based on an unjustifiable standard such as race, religion, or otlier arbitrary classification."11

Similarly, in Blackledge v. Perry, ${ }^{12}$ the Court overturned a defendant's remdictment on more serious cliarges after a successful appeal. Because the remdictment was expressly intended to punish the defendant for appealing, the prosecutor's motivation was unconstitutionally vindictive. In United States v. Falk, ${ }^{13}$ the Court of Appeals for the Seventh Circuit held that it was impermissible for the prosecutor to decide to cliarge an individual because of the individual's political activities protected by the first amendment. ${ }^{14}$ Courts also have intervened when the prosecutor's cliarging decision is imtended to limit the exercise of procedural riglits such as suppressing evidence ${ }^{15}$ or seeking a venue cliange. ${ }^{16}$

This line of cases suggests that a prosecutor, in nnaking a cliarging decision, should not be allowed to take into account the particular defendant's desire to exercise legal rights. ${ }^{17}$ This judicial limitation on

11. Id. at 456 .

12. 417 U.S. 21 (1974).

13. 479 F.2d 616 (7th Cir. 1973).

14. This view has also been adopted by the courts of appeals of several other circuits. See, e.g., United States v. Steele, 461 F.2d 1148 (9th Cir. 1972); United States v. Berrios, 501 F.2d 1207 (2d Cir. 1974); United States v. Swanson, 509 F.2d 1205 (8th Cir. 1975); United States v. Bourque, 541 F.2d 290 (1st Cir. 1976). See also People v. Walker, 14 N.Y.2d 901, 206 N.E.2d 779, 252 N.Y.S.2d 96 (1964). In establishing the defense, the Court of Appeals for the Second Circuit set forth a two-prouged test for establishing discriminatory prosecution: (1) that others have not been prosecuted for conduct similar to defendant's; and (2) that the government's selection of the defendant for prosecution has been invidious or in bad faith, i.e, based upon such impermissible considerations as race, religion, or the desire to prevent the exercise of constitutional rights. United States v. Berrios, 501 F.2d 1207, 1211 (2d Cir. 1974).

The applicatiou of the first prong of this defense to the plea bargaining process concededly would be limited. When, for example, a prosecutor adopts a consistent policy of including in his charges additional counts solely for the purpose of convincing the defendant to forego his right to trial, cven before he learns of the defeudant's willingness to forego this right, the defense of unequal treatment would fail since all defendants are dealt with similarly. The second prong of the defense, however, would be useful in cases such as Hayes, where the prosecutor clearly singles out the defendant for enhanced charges in retaliation for defendant's intent to exercise the constitutioual right to jury trial.

15. United States v. Alvarado-Sandoval, 557 F.2d 645 (9th Cir. 1977).

16. United States v. DeMarco, 401 F. Supp. 505, 508 (C.D. Cal. 1975), affd, 550 F.2d 1224 (9th Cir.), cert. denied, 434 U.S. 827 (1977).

17. These cases must be read in conjunction with several cases concerning the vindictive couduct of judges. Blackledge v. Perry, 417 U.S. 21 (1974), which banned certain prosecutorial vindictiveness, was based in large part upon North Carolina v. Pearce, 395 U.S. 711 (1969), which reversed a more severe sentence given a defendant upon reconviction following a successful appeal. Because of the focus on vindictiveness, a complete prohibition on more severe treatment is 
prosecutorial discretion should apply with equal force to the plea bargaining process. The prosecutor must not be allowed to overcharge ${ }^{18}$ to discourage the defendant from goimg to trial.

The Hayes Court seemed to realize the existence of this chilling effect. ${ }^{19}$ However, the Court did not explicitly consider this issue. It focused instead on the administrative importance of plea negotiation. The Hayes opimion is one of several recent Supreme Court decisions which treat the plea bargaining process as an cssential component of today's criminal justice system. ${ }^{20}$ Hayes indicates that-because of heavily burdened criminal courts-a defendant's decision to insist upon the right to trial is less protected than decisions involving the assertion of other rights discussed above. ${ }^{21}$

not required. When the trial court or prosecutor makes an affirmative showing, in the record, of the new reasons which justify more severe treatment upon reconviction, due process is not violated. Blackledge v. Perry, 417 U.S. 21, 29 n.7 (1974); North Carolina v. Pearce, 395 U.S. 711, 726 (1969).

Other cases emphasize the improper subjective motivations of the prosecutor or judge. In Chaffm v. Stynchcoinbe, 412 U.S. 17 (1973), the Court held that a higher sentence may be imposed on retrial by a jury which is not informed of the defendant's successful appeal. The Court reasoned that the jury's ignorance of the prior history of the case would preclude a vindictive motive. In Colten v. Kentucky, 407 U.S. 104 (1972), a new judge hearing the case de novo was permitted to impose a higher sentence than the court below where there was nothing in the record which indicated that the judge was acting vindictively.

These cases indicate that a defendant's constitutioual rights are not infringed by all procedures which inay cause him or her to prefer, for tactical reasons, to waive the right to appeal. Chaffin v. Stynchcombe, 412 U.S. at 25.

18. See Parts IVA and IVB infra.

In this context, "overcharging" does not refer to the situation in which a prosecutor brings an indictmeut against a defendant when there is not probable cause to support the charge. That practice apparently is beyond the scope of the prosecutor's discretion even in the view of the Hayes majority. 434 U.S. at 364.

Proseeutors frequently exercise their discretion not to charge an individual with an offense where there is probable cause. Frank Miller, in Prosecution: The Decision to Charae A SuSPECT WITH A CRIME (1969), suggests a host of factors a prosecutor might cousider in deciding not to file a given charge, including: deference to strougly felt local attitudes, $i d$. at 183-85; awareness that an additional charge will not increase the sentence should the defendant be convicted, id. at 194-97; the age and "respectability" of the defendant, id. at 208; that the stigma of the offense will cause inore harm to the defendant than the prosecutor beheves appropriate, id. at 209; a recognition that the statutory minimum sentence for the offense is, in the prosecutor's view, unduly harsh, $i d$, at 210; a prosecutorial decision that probation is appropriate, when the prosecutor believes that the judge will concur if the defendant is not charged with the additional offense, id. at 211-12; a preference for civil sanctions, when they are available, id. at 241-52.

It also has been suggested that several considerations concerning the strength of the proseeutor's case might prompt the prosecutor not to indict a suspect on a particular charge. These include the suitability of the facts of the case as a test of uncertain law, the degree of criminality of the suspect's conduct, the weight of the evidence, the credibility of the witnesses, and the relative importance of the offense in relation to others demanding the prosecutor's time. See Pugach v. Klein, 193 F. Supp. 630, 635 (S.D.N.Y. 1961). See also United States v. Schullo, 390 F. Supp. 1067 (D. Minn. 1975).

19. 434 U.S. at 364.

20. Santobello v. New York, 404 U.S. 257 (1971); Blackledge v. Allison, 431 U.S. 63 (1977).

21. See notes 10-17 supra and accompanying text. The contrast between the judiciary's 
Lubricating the criminal justice systern is a worthy goal, but it does not justify infringing on the constitutionally protected right to trial-a right inore fundainental than the procedural rights that past cases so carefully guarded from arbitrary prosecutorial discretion. ${ }^{22}$ This is particularly true because courts can limit prosecutorial discretion of the type exercised in Hayes without sacrificing the administrative benefits of plea bargaining. The Hayes Court ignored these arguinents, and therefore upheld Hayes' conviction on enhanced charges when precedent suggested reversal.

III

\section{The "Mutuality of Advantage" Model of Plea BARGAINING}

The Hayes Court did not view the prosecutorial tactics in question as improperly coercive of the defendant's constitutional right to trial. ${ }^{23}$ Indeed, the Hayes majority suggested that condemning a prosecutor's use of his charging powers to induce guilty pleas "would contradict the very premises that underhe the concept of plea bargaining itself." 24 This conclusion does not follow from the constitutional premises underlying plea negotiations, because plea bargaining is not based on a need for coercive prosecutorial charging decisions. Plea bargaining is based instead on the "mutuahty of advantage" flowing both to the defendant and the state..$^{25}$

If the prosecutor's mitial charging decision is the result of a legitiinate exercise of discretion, a plea bargain in which one or more charges are dismissed in return for a guilty plea benefits each side.

desire to protect a defendant's right to trial and other rights is perhaps best illustrated by the district court's decision in Uinted States v. DeMarco, 401 F. Supp. 505 (C.D. Cal. 1975), affd, 550 F.2d 1224 (9th Cir.), cert. denied, 434 U.S. 827 (1977). In DeMarco the defendant was reindicted on inore serious charges following his snccessful inotion for a change of venue from the District of Columbia to his home in California. The district court in California dismissed the more severe charges and permitted the defendant's trial only on the original indictment. In response to the government's assertion that the practice of reindictment was appropriate since it was a part of the plea bargaining process, the court stated, "while plea bargaining may be necessary for the effective administration of criminal justice, veuue bargaining is hardly a necessary component of the prosecutor's arsenal." Id. at 511 .

22. See notes 10-17 supra and accompanying text.

23. Brady v. Umited States, 397 U.S. 742 (1970), recognized that those accused of crime are under pressure to plead guilty at every step of the criminal process. As long as defendants may plead guilty and waive their right to trial, some form of plea bargaining may be inevitable. If courts were to declare plea bargaining illegal, plea bargaining might be driven underground, out of public view and away from judicial control. See M. Heumann, Plea Bargaining 157-62. (1978). Even those wishing to preserve the defendant's right to trial should prefer a judiciallycontrolled, open plea bargaining system.

24. 434 U.S. at 365.

25. Id. at 363. See also Parker v. North Carolina, 397 U.S. 790, 809 (1969) (Breunan, J., concurring). 
Hayes distorts this "mutuality of advantage" model. The decision allows a prosecutor to apply leverage by filing charges that would not have been brought against the defendant absent plea bargaining considerations. Superficially, the defendant appears to receive a benefit if the prosecutor agrees to dismiss the added charges in exchange for a guilty plea. In fact, however, the defendant is no better off since the added charges should not liave been brought in the first instance. ${ }^{26}$

Hayes removes the plea bargaining process froin the "mutuality of advantage" model and legitimizes coercing defendants to waive their constitutionally protected right to trial. This result would have been avoided had the Court stated that prosecutors may not permit tactical considerations to influence their charging decisions.

IV

\section{Judicial Restraints on Prosecutorial Discretion IN Plea Bargaining}

It may be difficult to determine whether inducing a guilty plea is the motive for mitial charging decisions. ${ }^{27}$ But this difficulty does not justify the Supreme Court stating that it is constitutionally proper for a prosecutor to threaten to add additional charges to imduce the defendant to forego trial on the first charges.

The prosecutor, of course, can avoid a rule prohibiting "threats to reindict" simply by adding extra charges in the original imdictment or information..$^{28}$ Justice Blackmun, dissenting in Hayes, suggested several reasons why even that praetice is preferable to "threats to reindict."

First, smce the plea bargaining system entrusts the prosecutor with awesome powers, both in decisions to charge and in decisions to drop charges im exchange for guilty pleas, public policy favors scrutiny of these decisions. ${ }^{29}$ Such scrutimy will result when the prosecutor must make all charges on the record in advance, and is not permitted to use unrecorded oral threats to achieve plea bargains. Second, requiring a grand jury mdictment to a limited extent screens improper charges. It inay therefore be improper to give the prosecution the advantage of bargaining with an unknown-the threat of a future imdictment that a

26. In theory the defendant may choose to forego his right to trial to avoid "the anxieties and uncertainties of a trial" and to obtain "a speedy disposition of his case, the chance to acknowledge his guilt, and a prompt start in realizing whatever potential there may be for rehabilitation," Blackledge v. Allison, 431 U.S. 63, 71 (1977). In fact most defendants are receptive to plea bargains because of the opportunity for leniency.

27. Bordenkircher v. Hayes, 434 U.S. at $371 \mathrm{n.2}$ (Powell, J., dissenting).

28. Id. at 368-69 n.2 (Blackmun, J., dissenting).

29. Id. 
grand jury might be unwilling to return. ${ }^{30}$

In any event, enforcing any rule designed to preserve the "mutuality of advantage" between prosecutor and defendant depends to a large extent on the trial judge's discretion. The following suggests how the trial judge should exercise that discretion. ${ }^{31}$

\section{A. Subsequent Addition of More Serious Charges}

Where a prosecutor reindicts a defendant on more serious charges following a breakdown in plea negotiations, but does not justify the new indictment on the record for reasons independent of the bargaining process, it should be inferred that the prosecutor was improperly motivated by a desire to force the defendant to forgo a trial. In this case, the new indictment should be dismissed. This was the case in Hayes.

\section{B. Initial Overcharging}

Where the trial judge is convimced that multiple charges have been mcluded in an original indictment or information solely for plea bargaining purposes, the extra charges should be dismissed and the prosecutor and defendant should be directed to renegotiate the plea in light of the modified set of charges. Overcharging requiring this sort of rehef could occur in two forms. "Horizontal" overcharging is present where a prosecutor includes additional counts of the same substantive offense, intending to dismiss a number of them in return for a guilty plea. "Vertical" overcharging occurs where a prosecutor imcludes different substantive offenses in the initial charge, again intending to dismiss one or more of them.

Vertical overcharging is the more abusive of the two practices. The threat of severe punishment for multiple substantive offenses places extra pressure on the defendant to plead guilty to a single charge. ${ }^{33}$ In order to mitigate this problem, the trial judge should ex-

30. Id. See also Santobello v. New York, 404 U.S. 257, 261 (1971), where the Court said that a constitutional plea bargaining process "presupposes fairness in securing an agreement between an accused and a prosecutor."

31. The following discussion is not an exhaustive evaluation of the possible means by which courts can control abuses of the prosecutor's decision to charge in the context of plea bargaining. These proposals, and others, may pose administrative difficulties. The alternative, however, of unfettered prosecutorial discretion in the charging decision-including deliberate use of the charging power to coerce defendants to waive their right to trial-is less desirable.

32. See Alschuler, The Prosecutor's Role in Plea Bargaining, 36 U. CHI. L. REv. 50, 85-86 (1968).

33. For example, a defendant who is unable to post bail may be allowed to plead guilty to a misdemeanor, receive probation and credit for time served, and be eligible for immediate release rather than be indicted for a felony which might subject the accused to a lengthy term in the state penitentiary if convicted. See, e.g., Mills, I Have Nothing to do With Justice, LIFE, Marcl 12, 1971 , at 56. 
amine the disparity between the charges initially filed and those to which the defendant ultimately pleads guilty. When the difference is significant, the judge should infer (absent a satisfactory explanation from the prosecutor) that the multiple charges were included only for the prosecutor's plea bargaining advantage.

The abuse of horizontal overcharging is less severe because defendants frequently are given concurrent sentences upon multiplecount convictions. Nor is the remedy for horizontal overcharging likely to be effective. When, for example, a defendant pleads guilty to one count in return for disinissal of nine identical ones, it is unlikely that any different bargain will be struck if the court orders the imitial charge reduced to five counts. In such a case, the defendant probably would again plead guilty to one count im exchange for the dismissal of the remaining four.

\section{Promulgation of Regulations}

In addition to the remedial efforts which have been mentioned, prosecutors should be required to promulgate, and adhere to, regulations governing charging decisions. ${ }^{34}$ Bargaining advantage should not be a factor in these decisions. When a court determines that a defendant has been charged with an offense that should not have been brought under the regulations, it could disimiss the charges and order that a plea bargam be renegotiated im light of the reduced charges.

\section{Questioning the Prosecutor}

The trial judge also inight permit the defense to subpoena and question the prosecuting attorney and others in the prosecutor's office about the decision to charge. ${ }^{35}$ A vigilant public defender's office could, by examining the original charges brought by the prosecutor over a period of time detect cases in which a defendant is being singled out for harsher treatment because of plea bargaining considerations. A public defender nnight likewise be able to detect whether the prosecutor consistently included charges usually later disınissed in return for guilty pleas. If trial courts were willing to dennand explanations of charging decisions, prosecutors inight theinselves develop standards to regulate these decisions. Little delay and armoyance will result from

34. This has been suggested by the American Law Institute. MODEL Code OF PRE-ARRaignment Procedure \& 350.3(2) (P.O.D. 1975). The Model Code, however, would not permit a defendant to use a violation of the Code's provisions collaterally to attack a conviction. Id. § 350.9. Furthermore, the Code does not forbid the prosecutor from consistently overcharging to obtain a favorable bargaining position, as long as the defendant is charged with a crime the prosecutor beheves is provable. Id. $\S 350.3(3)$.

35. This is done in the "discriminatory prosecution" cases. See, e.g., United States v. Falk, 479 F.2d 616, 620 (7th Cir. 1973). 
this inquiry if a prosecutor quickly can point to regulations to explain why charges were brought against the defendant.

\section{CONCLUSION}

Hayes seems to portend a trend away from jury trial toward a prosecutor's administrative decision as the mechanism for determining the guilt and innocence of criminal defendants. This trend is particularly dangerous because the Hayes Court refused to control the process by which the prosecutor makes these important decisions.

The plea bargaining process may be essential to the effective functioning of the criminal justice system. It nevertheless can present significant risks of coercing defendants to waive their constitutional right to trial. Since plea bargaining derives its constitutional legitimacy from the "mutuality of advantage" enjoyed by the prosecutor and the defendant, only a plea bargain that involves a real benefit in the form of lement treatment to the defendant as well as administrative convenience to the government keeps the element of coercion within constitutional limits. The "mutuality of advantage" model of plea bargaining is not inconsistent with an administratively effective process. The prosecutor's cliarging decision need not be a weapon in the plea bargaining arsenal. As long as some real advantage remains for the defendant, pleas will continue to be negotiated effectively.

Stephen F. Ross*

* A.B. 1976, University of California, Berkeley; third-year student, Boalt Hall School of Law. 


$$
\text { . }
$$

